\title{
Leaching of nitrogen in barley, grass ley and fallow lysimeters
}

\author{
TOIVO YLÄRANTA, JAANA UUSI-KÄMPPÄ and ANTTI JAAKKOLA
}

\begin{abstract}
YLÄRANTA, T., UUSI-KÄMPPÄ, J. \& JAAKKOLA, A. 1993. Leaching of nitrogen in barley, grass ley and fallow lysimeters. Agric. Sci. Finl. 2: 281-291. (Agric. Res. Centre of Finland, Inst. Soils and Environ., FIN-31600 Jokioinen, Finland and Dept. Appl. Chem. \& Microbiol., P.O. Box 27, FIN-00014 University of Helsinki, Finland.)

The leaching of nitrogen from fallow, fertilized and unfertilized spring barley, and grass ley was studied in a 4-year lysimeter experiment carried out on clay, silt and sand soils, and Carex peat. The experimental factors included also irrigation and treatments where the nitrogen fertilizer was applied in the first year as ${ }^{15} \mathrm{~N}$-labelled ammonium nitrate.

During four years, $41-66 \%$ of the nitrogen applied in the first growing season was recovered in plants harvested. Most of it, $91-96 \%$, was taken up in the year applied.

Mostly, the water drainage was lowest in silt and sand soils. The irrigation increased clearly the leaching of nitrogen almost in all treatments. Crops decreased the drainage of water through the lysimeters and the leaching of nitrogen, grass more than barley.

The effects of plants and irrigation were similar in all soils, but most marked in sand. The largest amount of nitrogen was leached in irrigated, fallowed sand, $440 \mathrm{~kg} \mathrm{ha}^{-1}$, during four years.

The majority of the leached nitrogen was nitrate. Only in peat soil a significant amount of nitrogen was leached in some another form.

The leaching of ${ }^{15} \mathrm{~N}$-labelled fertilizer during four years was highest in sand, 2.3 $\mathrm{kg} \mathrm{ha}^{-1}$ of $\mathrm{N}$ or $2.3 \%$ of the nitrogen applied in the first experimental year.
\end{abstract}

Key words: Nitrogen leaching, ${ }^{15} \mathrm{~N}$, irrigation, lysimeter experiment, barley, grass, fallow

\section{Introduction}

Water contamination by nitrates is an increasing concern in Europe and is generally considered to be closely connected with the intensification of agriculture and increasing use of nitrogen fertilizers. The three main pathways in which nitrogen is lost from agricultural fields are leaching, denitrification and volatilization (SCHARF and ALLEY 1989). Commonly, the greatest losses are due to leaching.

The amount of nitrogen lost due to leaching is extremely variable. Environmental factors, such as precipitation, can drastically change the nitrogen balance within the soil. Low precipitation can lead to extremely low leaching losses. Perennial grass leys have been shown to efficiently take up fertilizer nitrogen, thereby minimizing leaching (BERGSTRÖM 1987).

The deposition of nitrogen in precipitation has been recorded and included in nitrogen balance studies in Central Europe for many years. In Finland, the deposition of nitrogen is commonly lower than $10 \mathrm{~kg} \mathrm{ha}^{-1} \mathrm{a}^{-1}$ (LEINONEN and JUNTTO 1992). Therefore, this is no important factor in nitrogen balance studies in Finland. The major input of nitrogen comes from the fertilizers, in Finland about 100 $\mathrm{kg} \mathrm{ha}^{-1} \mathrm{a}^{-1}$ during the last few years on average.

The aim of the present study was to investigate 
the effects of different vegetations, barley and perennial grass ley, compared to bare fallow on the leaching of nitrogen in the different soils. The experiment consisted of fertilized and unfertilized treatments with and without irrigation because nitrogen leaching can be highly affected by irrigation. In order to facilitate the comparison of nitrogen behaviour in different soils under identical experimental conditions, a lysimeter field established in 1981 by JAAKKOLA (1984) was used in this study.

Use of ${ }^{15} \mathrm{~N}$-labelled fertilizer enables discrimination between fertilizer nitrogen and other plantavailable nitrogen in the soil. Therefore, ${ }^{15} \mathrm{~N}$-labelled ammonium nitrate applied in the first experimental year was used in this experiment.

\section{Material and methods}

The lysimeter field, described in detail by JAAKKOLA (1984), consisted of 96 containers, 0.9 $\mathrm{m}$ in diameter and $1.7 \mathrm{~m}$ deep. The soils in the lysimeters were clay, silt, sand and Carex peat. Twenty-two lysimeters were filled with each soil (Table 1). In addition, two lysimeters of each soil were taken as undisturbed monoliths.

The experiment was established in spring 1983 at the same time in 20 filled lysimeters for each of the four experimental soils. The trial comprised irrigated and unirrigated treatments (replicated twice) as follows:

\section{Fallow}

2. Unfertilized spring barley (Hordeum vulgare)

3. Fertilized barley

4. Unfertilized barley followed by timothy (Phleum pratense)-meadow fescue (Festuca pratensis)

5. Fertilized barley followed by timothy-meadow fescue

In 1983, barley grown on all mineral soils was fertilized with $39.8 \mathrm{~g}$ of NPK compound fertilizer $(16 \% \mathrm{~N}, 7 \% \mathrm{P}, 13 \% \mathrm{~K})$ per lysimeter or $16.0 \mathrm{~g}$ ammonium nitrate $\left(20 \%{ }^{15} \mathrm{NH}_{4}{ }^{15} \mathrm{NO}_{3}\right)$ and $38.2 \mathrm{~g}$ ammoniated PK fertilizer ( $2 \% \mathrm{~N}, 8 \% \mathrm{P}, 12 \% \mathrm{~K})$. The nitrogen fertilization was in both cases equal,
Table 1. Properties of soils in the lysimeters. Carex peat was clayed containing therefore only $14.4 \%$ of organic carbon in the $0-20 \mathrm{~cm}$ layer.

\begin{tabular}{lcrrrr}
\hline & Depth, cm & \multicolumn{4}{c}{ Soil } \\
\cline { 3 - 6 } & & Clay & Silt & Sand & Peat \\
\hline \multirow{2}{*}{ Org. C, \% } & $0-20$ & 3.6 & 2.7 & 3.1 & 14.4 \\
pH $\left(\mathrm{H}_{2} \mathrm{O}\right)$ & $0-20$ & 5.8 & 6.0 & 5.9 & 5.6 \\
& $20-40$ & 5.8 & 6.5 & 6.0 & 4.7 \\
& $40-80$ & 6.6 & 7.0 & 6.2 & 4.8 \\
& $80-115$ & 7.0 & 7.0 & 6.3 & 5.2 \\
Particle size distribution, \% & & & & \\
$<0.002 \mathrm{~mm}$ & $0-20$ & 46 & 17 & 13 & 62 \\
& $20-40$ & 58 & 17 & 4 & - \\
& $40-80$ & 54 & 24 & 6 & - \\
& $80-115$ & 54 & 16 & 9 & - \\
$0.002-0.02 \mathrm{~mm}$ & $0-20$ & 15 & 62 & 8 & 8 \\
& $20-40$ & 13 & 66 & 3 & - \\
& $40-80$ & 14 & 64 & 3 & - \\
& $80-115$ & 18 & 51 & 4 & - \\
$0.02-0.06 \mathrm{~mm}$ & $0-20$ & 17 & 14 & 16 & 3 \\
& $20-40$ & 16 & 13 & 11 & - \\
& $40-80$ & 22 & 10 & 12 & - \\
& $80-115$ & 20 & 30 & 16 & - \\
& $0-20$ & 10 & 3 & 42 & 11 \\
& $20-40$ & 9 & 2 & 65 & - \\
& $40-80$ & 9 & 1 & 69 & - \\
& $80-115$ & 7 & 3 & 67 & - \\
\hline
\end{tabular}

$10 \mathrm{~g} \mathrm{~m}^{-2}$ of $\mathrm{N}$ or $100 \mathrm{~kg} \mathrm{ha}^{-1}$ of $\mathrm{N}$. The fertilization of peat soil was in each lysimeter $31.8 \mathrm{~g}$ of NPK compound fertilizer $(10 \% \mathrm{~N}, 9 \% \mathrm{P}, 17 \% \mathrm{~K})$ enriched with boron or $6.9 \mathrm{~g}$ of ammonium nitrate $\left(69 \%{ }^{15} \mathrm{NH}_{4}{ }^{15} \mathrm{NO}_{3}\right)$ and $38.2 \mathrm{~g}$ of ammoniated $\mathrm{PK}$ fertilizer. This fertilization contained $5 \mathrm{~g} \mathrm{~m}^{-2}$ of $\mathrm{N}$, which equalled to $50 \mathrm{~kg} \mathrm{ha}^{-1}$ of $\mathrm{N}$. ${ }^{15} \mathrm{~N}$-labelled fertilizer was applied only to one lysimeter in each treatment. ${ }^{15} \mathrm{~N}$-labelled nitrogen was not given after the establishment of the experiment in 1983.

In the growing seasons 1984-1987, barley grown in clay, silt and sand got $39.8 \mathrm{~g}$ of NPK per lysimeter, being equivalent to $100 \mathrm{~g} \mathrm{ha}^{-1}$ of $\mathrm{N}$. The fertilization in peat soil consisted of $31.8 \mathrm{~g}$ of NPK enriched with boron (10-9-17), being equal to 50 $\mathrm{kg} \mathrm{ha}^{-1}$ of $\mathrm{N}$. Timothy-meadow fescue ley grown in 1984-1986 got the same fertilizer as did barley, but it was given twice a year. The fertilization was the same in spring and later in the growing season for a 
second yield, i.e. $200 \mathrm{~kg} \mathrm{ha}^{-1}$ of $\mathrm{N}(100+100$ $\left.\mathrm{kg} \mathrm{ha}^{-1}\right)$ for mineral soils and $100 \mathrm{~kg} \mathrm{ha}^{-1}$ of $\mathrm{N}(50+$ $50 \mathrm{~kg} \mathrm{ha}^{-1}$ ) for peat soil. In the monolith lysimeters barley was grown without labelled nitrogen and irrigation. Otherwise, the monolith lysimeters were treated as the respective fertilized clay, silt, sand and peat lysimeters.

Irrigation was given on every growing season, totalling $1480 \mathrm{~mm}$ of water in 1983-1986: $290 \mathrm{~mm}$ (1983), $320 \mathrm{~mm}$ (1984), $390 \mathrm{~mm}$ (1985) and 480 $\mathrm{mm}$ (1986). In the beginning tap water was used. Since 4.8.1983 deionized water was used up to the end of the experiment.

The precipitation measured in the meteorological station $1 \mathrm{~km}$ away from the lysimeter field was during the experimental years as follows:

\begin{tabular}{lrc} 
Experimental year & Precipitation, mm \\
\hline 1983 & $13.5 .1983-7.5 .1984$ & 554 \\
1984 & $7.5 .1984-9.5 .1985$ & 726 \\
1985 & $9.5 .1985-5.5 .1986$ & 542 \\
1986 & $5.5 .1986-3.6 .1987$ & 665 \\
\hline
\end{tabular}

Total $2487 \mathrm{~mm}$

The results of water drainage and nitrogen leaching presented here are based on the experimental years, defined as a period between the beginning of two subsequent growing periods.

\section{Management of the experiment}

The top soil $(20 \mathrm{~cm})$ in each lysimeter was "ploughed" with a spade in autumn 1982. The next spring the surface soil of fallow lysimeters was raked up gently. The top $5 \mathrm{~cm}$ layer from each lysimeter was put aside and the fertilizers were applied to furrows surrounding the middle point of the lysimeter. After filling the furrows the seeds of barley (cv. Kustaa, 470 seeds per $\mathrm{m}^{2}$ ), sown in four rows surrounding the middle point of the lysimeters, were covered with the soil initially put aside, and the soil was compacted slightly. The seeds of timothy and meadow fescue were sown on the surface of the soil. The crop grown in the lysimeter was grown also on the soil surrounding the lysimeters, and the surrounding of fallow lysimeters was fallowed. During the growing season the fallow was harrowed gently with a rake in order to keep the soil surface free from any vegetation. From barley stand, weeds were taken away by hand.

Mature barley was cut into short stubble. The yields of grain and straw were weighed and sampled for the determination of moisture and nutrient content. After harvesting the soil in the barley and fallow lysimeters was "ploughed" with a spade to the depth of $20 \mathrm{~cm}$.

In 1984, the barley and fallow lysimeters were managed as in the previous year. The soils were treated as in the previous autumn and from the spring thereafter the same cultivation measures were repeated as in 1984 .

The soil samples, four cores in each lysimeter to the depth of $115 \mathrm{~cm}$, were taken after finishing the experiment in the spring 1987. The cores were divided into six layers for ${ }^{15} \mathrm{~N}$ analysis. The water drained through the lysimeters was collected in polyethylene cans. The cans were weighed and emptied as often as necessary, in the summer usually once every two weeks. At the same time, onelitre water samples were taken from each can for laboratory analyses. In some years, especially in the autumns when water was abundantly percolated through the lysimeters, it was necessary to combine successive water samples in order to diminish the number of analyses. Water samples were pooled in the same proportion as the water drained. The water samples were stored at $+4^{\circ} \mathrm{C}$ and analyzed as soon as possible. The water samples containing labelled ${ }^{15} \mathrm{~N}$ were deep-frozen until determination of ${ }^{15} \mathrm{~N}$.

\section{Analytical methods}

The plant samples were analysed for total nitrogen with the Kjeltec system (Tecator, Sweden). The ${ }^{15} \mathrm{~N}^{14} \mathrm{~N} /{ }^{14} \mathrm{~N}^{14} \mathrm{~N}$ ratio was measured with a Micromass 622 mass spectrometer (VG Analytical Ltd, U.K.) and the ${ }^{15} \mathrm{~N} /{ }^{14} \mathrm{~N}$ ratio was calculated. The analytical methods have been described in detail by JAAKKOLA (1985). The nitrogen taken up by the plant from the fertilizer was calculated according to method described by JAAKKOLA (1985).

The water samples were analyzed for total, nitrate and ammonium nitrogen by an AKEA 
autoanalyzer (Datex, Finland) according to the methods described by JAAKKOLA (1985), and JAAKKOLA and YLÄRANTA (1985). The content of ${ }^{15} \mathrm{~N}$ in nitrate and ammonium nitrogen was determined only from those water samples where the total content of nitrate and ammonium nitrogen was at least $1 \mathrm{mg} \mathrm{l}^{-1}$.

The soil samples taken at the end of the experiment were analyzed for total content of ${ }^{15} \mathrm{~N}$. The soil was digested for this analysis as the plant material.

The means of two replications are presented as final results except in the lysimeters where ${ }^{15} \mathrm{~N}$-labelled nitrogen had been applied, because ${ }^{15} \mathrm{~N}$ treatments were not replicated.

\section{Results}

In the fertilized lysimeters the barley grain yields varied from year to year and in different soils from
2500 to $5500 \mathrm{~kg} \mathrm{ha}^{-1}$. The yield variations were great in unfertilized lysimeters. The total dry matter yields harvested, i.e. the sum of grain and straw yields was in some cases over $10000 \mathrm{~kg} \mathrm{ha}^{-1}$. In monolith lysimeters they were commonly smaller than in respective fertilized and filled lysimeters. In the fertilized lysimeters the annual grass yield varied from 2900 to 7000 , in the unfertilized ones from 1000 to $4100 \mathrm{~kg} \mathrm{ha}^{-1}$ dry matter. On average, the effect of irrigation on the barley and grass yields was small. The highest uptake of nitrogen by plants was in grass treatments (Fig. 1). The effect of irrigation on the nitrogen uptake was small.

During the whole experimental period, 600-2700 $\mathrm{mm}$ of water was drained through the lysimeters. The highest drainage, $2700 \mathrm{~mm}$ during four years, was measured in the fallow treatment. The irrigation increased clearly the water drainage. In unirrigated lysimeters the drainage was highest in clay and peat soil, i.e. $1000-1500 \mathrm{~mm}$, and lowest in silt

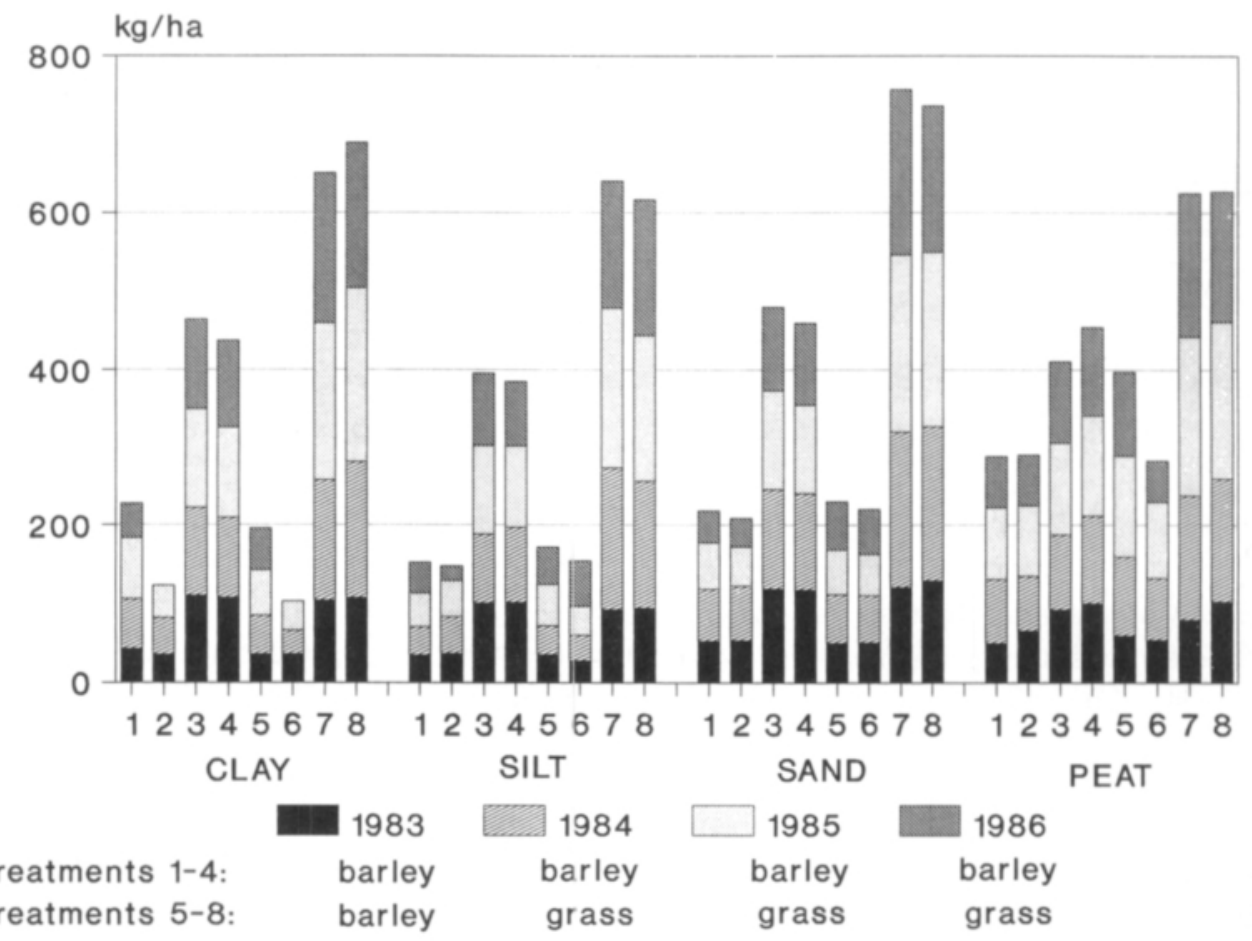

Fig. 1. Total uptake of nitrogen by barley and grass ley in lysimeters with and without irrigation in 1983-1987. Treatments: 1 and $5=$ unfertilized; 2 and $6=$ unfertilized+irrigated; 3 and $7=$ fertilized; 4 and $8=$ fertilized+irrigated. In grass treatments the yields in 1983 are the sum of barley straw and grain. Because of the failures in treatments 2 and 6 in clay lysimeters, nitrogen uptake in 1986 is not presented. 


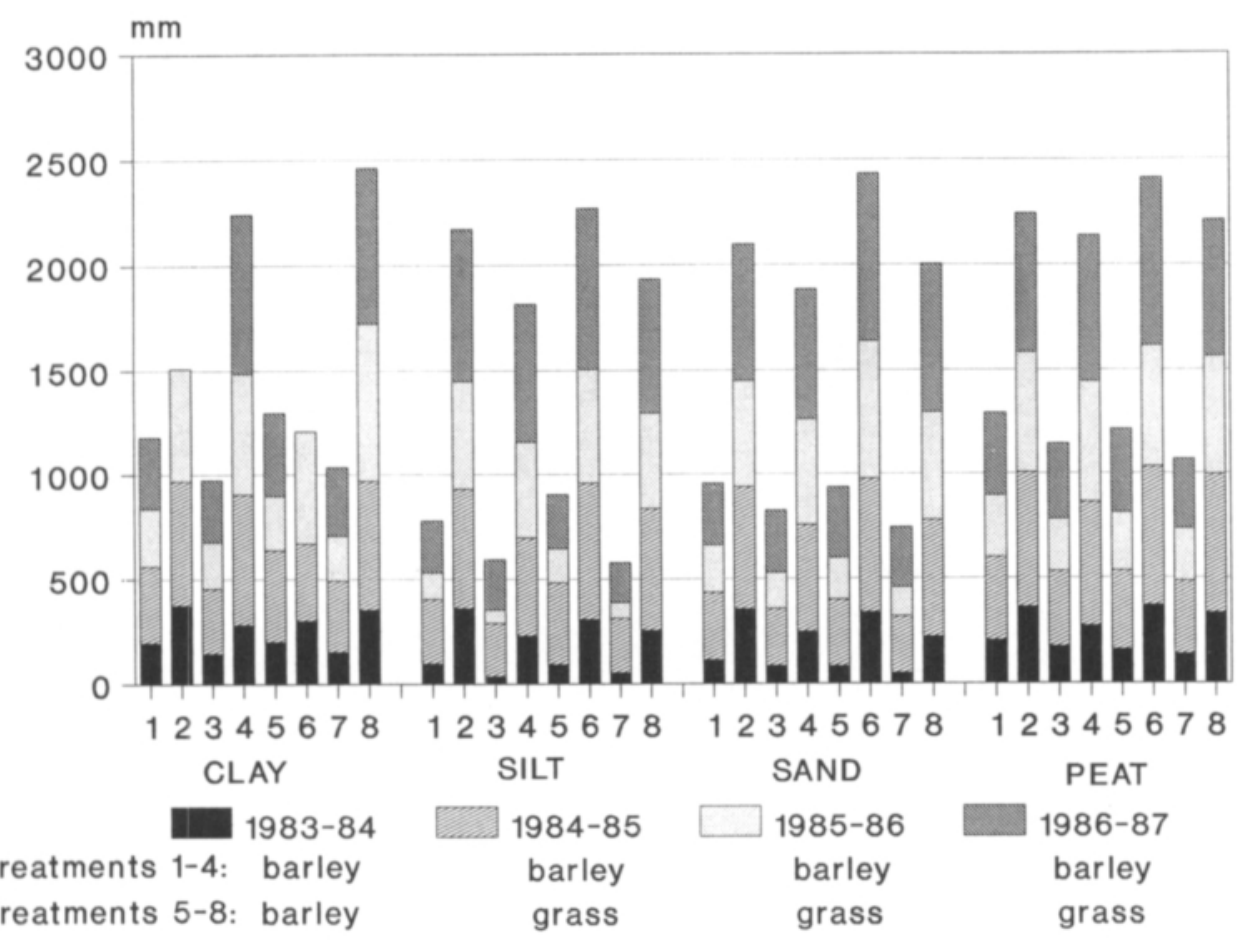

Fig. 2. Water drainage through barley and grass ley lysimeters with and without irrigation in 1983-1987. Treatments as in Fig. 1.

soil (Fig. 2). The drainage was $100-300 \mathrm{~mm}$ higher in unfertilized lysimeters than in the fertilized ones.

The water drainage through the soil was slightly smaller in unirrigated fertilized monolith lysimeters grown barley than in respective filled lysimeters, $\mathrm{mm}$ in 1983-1987:

\begin{tabular}{lcc} 
& $\begin{array}{c}\text { Monolith } \\
\text { lysimeters }\end{array}$ & $\begin{array}{c}\text { Filled } \\
\text { lysimeters }\end{array}$ \\
\hline Clay & 760 & 980 \\
Silt & 490 & 590 \\
Sand & 600 & 830 \\
Peat & 1100 & 1140 \\
\hline
\end{tabular}

The nitrogen leaching was highest in fallow, varying, however, widely during different experimental periods and in the different soils (Table 2). In most cases the irrigation increased greatly the leaching. The losses during four years were greatest in irrigated sand soil $\left(440 \mathrm{~kg} \mathrm{ha}^{-1}\right)$, where the water drainage was $2450 \mathrm{~mm}$. The nitrogen leaching was lowest in peat fallow. However, the concentration of nitrate nitrogen in drainage water samples exceeded only twice slightly the EEC limit for potable water of $11.3 \mathrm{mg} \mathrm{l}^{-1}$ (EEC 1980).

Crops decreased effectively nitrogen leaching, grass more than barley. In cropped, unfertilized treatments the nitrogen loss was greatest in sandy soil growing barley (Fig. 3). Usually fertilization affected the $\mathrm{N}$ losses slightly, whereas irrigation increased them clearly.

On average, more than $90 \%$ of the nitrogen leached through the lysimeters in the mineral soils was in the form of nitrate and commonly less than $1 \%$ in the form of ammonium. The form of the rest of nitrogen leached was not determined. In cropped peat, less than half of the total nitrogen leached consisted of nitrate and ammonium nitrogen. Obviously, a great portion was in organic form. The proportion of nitrate and ammonium nitrogen compared to the total nitrogen leached was in fertilized 
Table 2. Leaching of nitrogen in unirrigated and irrigated fallow lysimeters in 1983-1987, $\mathrm{kg} \mathrm{ha}^{-1} \mathrm{a}^{-1}$.

\begin{tabular}{lccccc}
\hline \multirow{2}{*}{$\begin{array}{l}\text { Soil and } \\
\text { treatment }\end{array}$} & \multicolumn{5}{c}{ Experimental year } \\
\cline { 2 - 6 } Clay & $1983-84$ & $1984-85$ & $1985-86$ & $1986-87$ & Totally \\
Unirrigated & 8 & 71 & 72 & 110 & 261 \\
Irrigated & 46 & 102 & 101 & 131 & 380 \\
Silt & & & & & \\
Unirrigated & 3 & 18 & 17 & 56 & 94 \\
Irrigated & 17 & 51 & 58 & 56 & 409 \\
Sand & 31 & 141 & 89 & 148 & 437 \\
Unirrigated & 71 & 150 & 96 & 120 & \\
Irrigated & & & & & 24 \\
Peat & 1 & 8 & 10 & 5 & 93 \\
Unirrigated & 6 & 26 & 31 & 30 & \\
Irrigated & & & & & \\
\hline
\end{tabular}

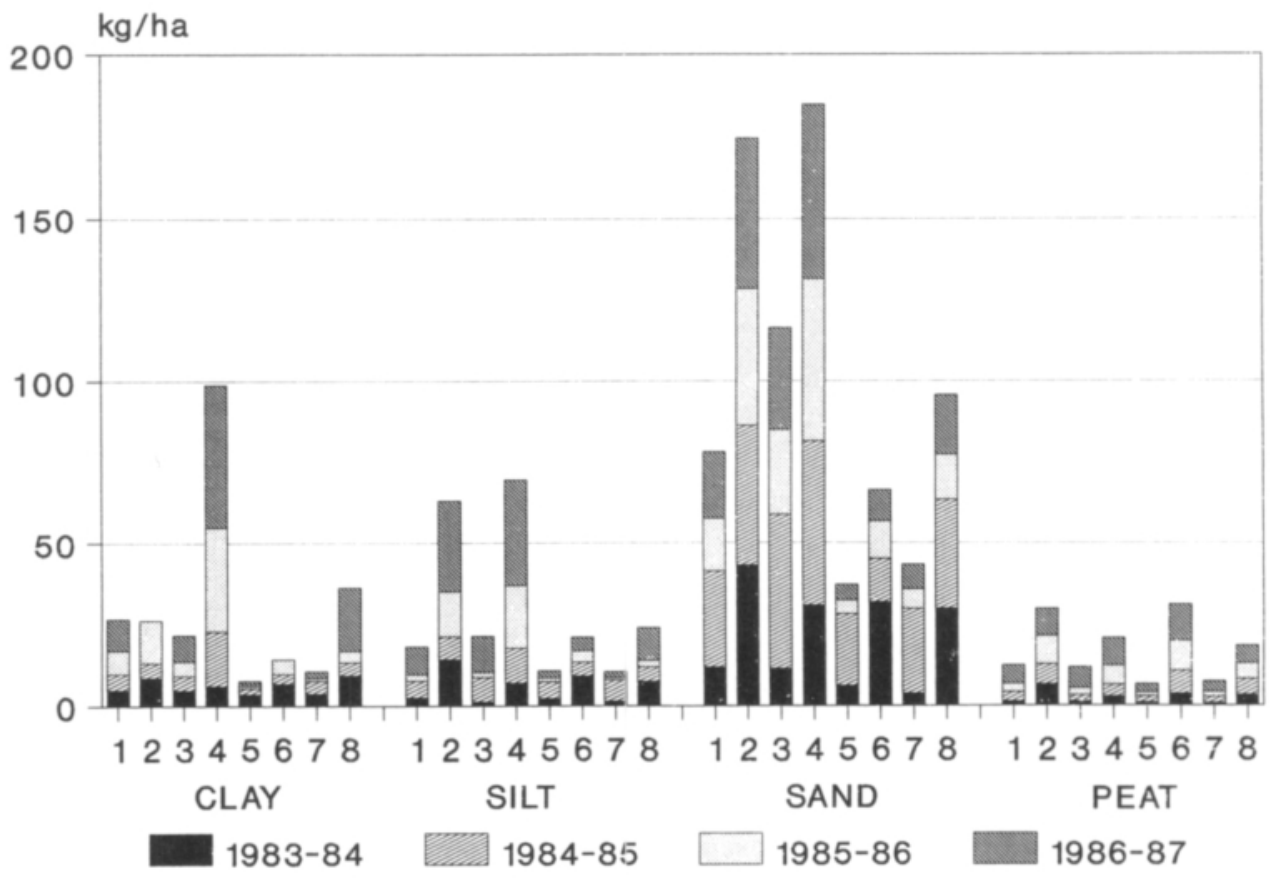

Fig. 3. Leaching of total nitrogen from barley and grass ley lysimeters with and without irrigation in 1983-1987. Treatments as in Fig. 1. There was no leaching in clay soil in the last experimental year (columns 2 and 6).

cropped treatments greater than in corresponding unfertilized treatments. On average, in fallow treatment of peat lysimeters, $75 \%$ of nitrogen leached was in the form of nitrate and $10 \%$ in the form of ammonium.

The leaching of nitrogen was higher in the mono- 


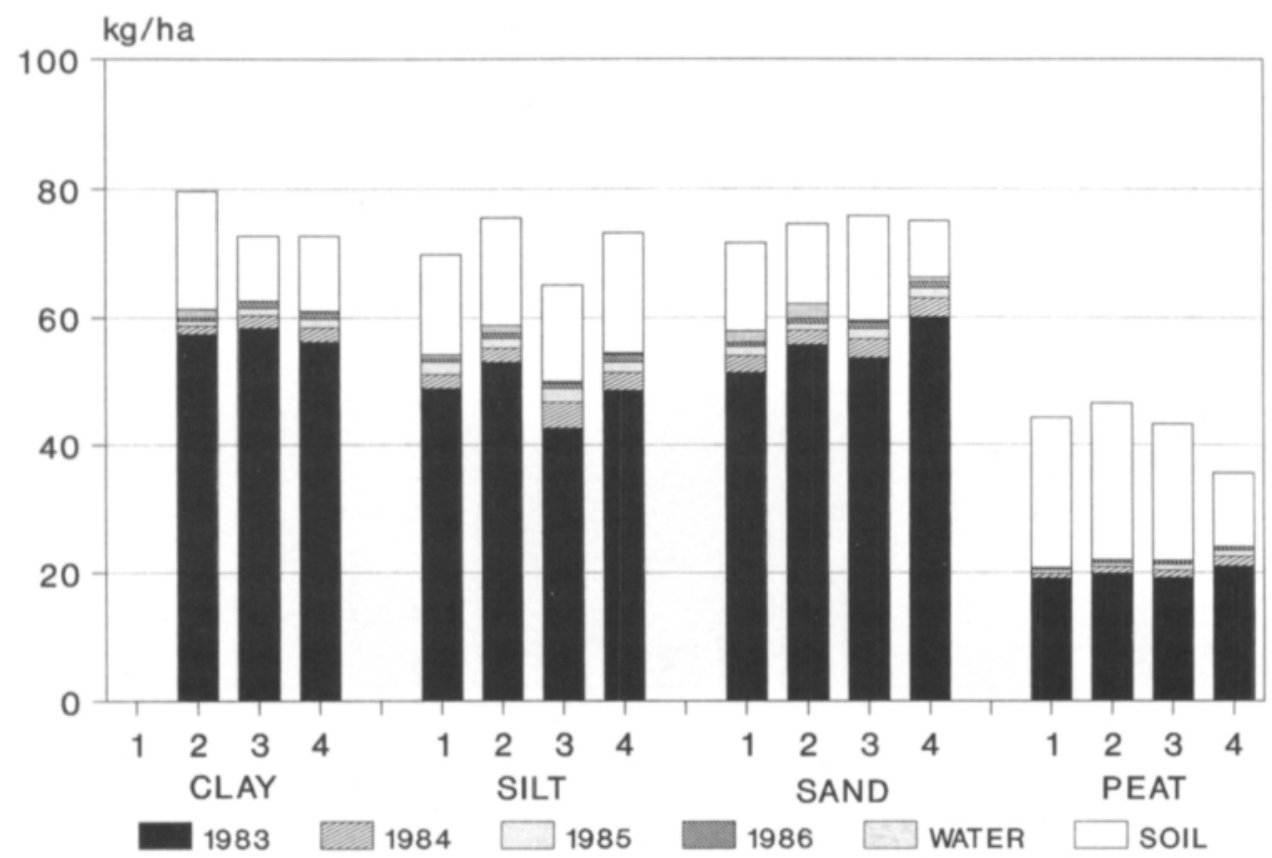

Fig. 4. Recovery of ${ }^{15} \mathrm{~N}$-labelled nitrogen (in $1983100 \mathrm{~kg} \mathrm{ha}^{-1}$ of $\mathrm{N}$ was added to mineral soils and $50 \mathrm{~kg} \mathrm{ha}{ }^{-1}$ of $\mathrm{N}$ to peat soil) in barley and grass ley harvested in 1983-1986, in the drainage water in 1983-1987 and in the soil profiles at the end of the experiment in 1987. Treatments: $1=$ unirrigated barley; $2=$ irrigated barley; 3 = unirrigated grass ley; and $4=$ irrigated grass ley. Because of the failures in clay lysimeters column 1 (clay soil) is omitted.

lith lysimeters grown barley than in the other lysimeters excluding sand soil $\left(\mathrm{kg} \mathrm{ha}^{-1}\right.$, in 19831987):

\begin{tabular}{lccrr}
\hline & \multicolumn{2}{c}{$\begin{array}{c}\text { Monolith } \\
\text { lysimeters }\end{array}$} & \multicolumn{2}{c}{$\begin{array}{c}\text { Filled } \\
\text { lysimeters }\end{array}$} \\
& Total-N & Nitrate-N & Total-N & Nitrate-N \\
\hline Clay & 49 & 47 & - & - \\
Silt & 43 & 41 & 21 & 20 \\
Sand & 64 & 62 & 116 & 112 \\
Peat & 42 & 35 & 12 & 7 \\
\hline
\end{tabular}

Because of the failures in the functioning of filled clay soil lysimeters and, conseguently the lack of data in some experimental period, it was impossible to give total nitrogen and nitrate values for them.

During four experimental years, the total recovery of the ${ }^{15} \mathrm{~N}$-labelled nitrogen varied from 65 to 93\% (Fig. 4). In the barley grain and straw, $41-60 \%$ of the nitrogen added in 1983 was recovered (Fig. 4). The main part of recovered nitrogen, $70-80 \%$, occurred in the grain. The uptake of labelled nitrogen by barley was smallest in peat soil, slightly over $40 \%$. Of the total uptake, the first-year barley took up $91-96 \%$. The uptake did not vary considerably in different soils, but it decreased with time. In the last growing season, 1986 , less than $1 \%$ of the labelled nitrogen added in 1983 was recovered in barley grain and straw on average.

Barley was sown as a companion crop with grass ley. Therefore, in grass lysimeters labelled nitrogen was analyzed in 1983 in barley grain and straw. In those treatments $42-60 \%$ of labelled nitrogen was recovered, which equals to the amounts found also in lysimeters grown continuous barley. During later growing seasons the grass ley took up totally $4-7 \%$ of the labelled nitrogen. Thus, the total uptake by grass was $44-66 \%$.

The leaching of labelled nitrogen was very small 


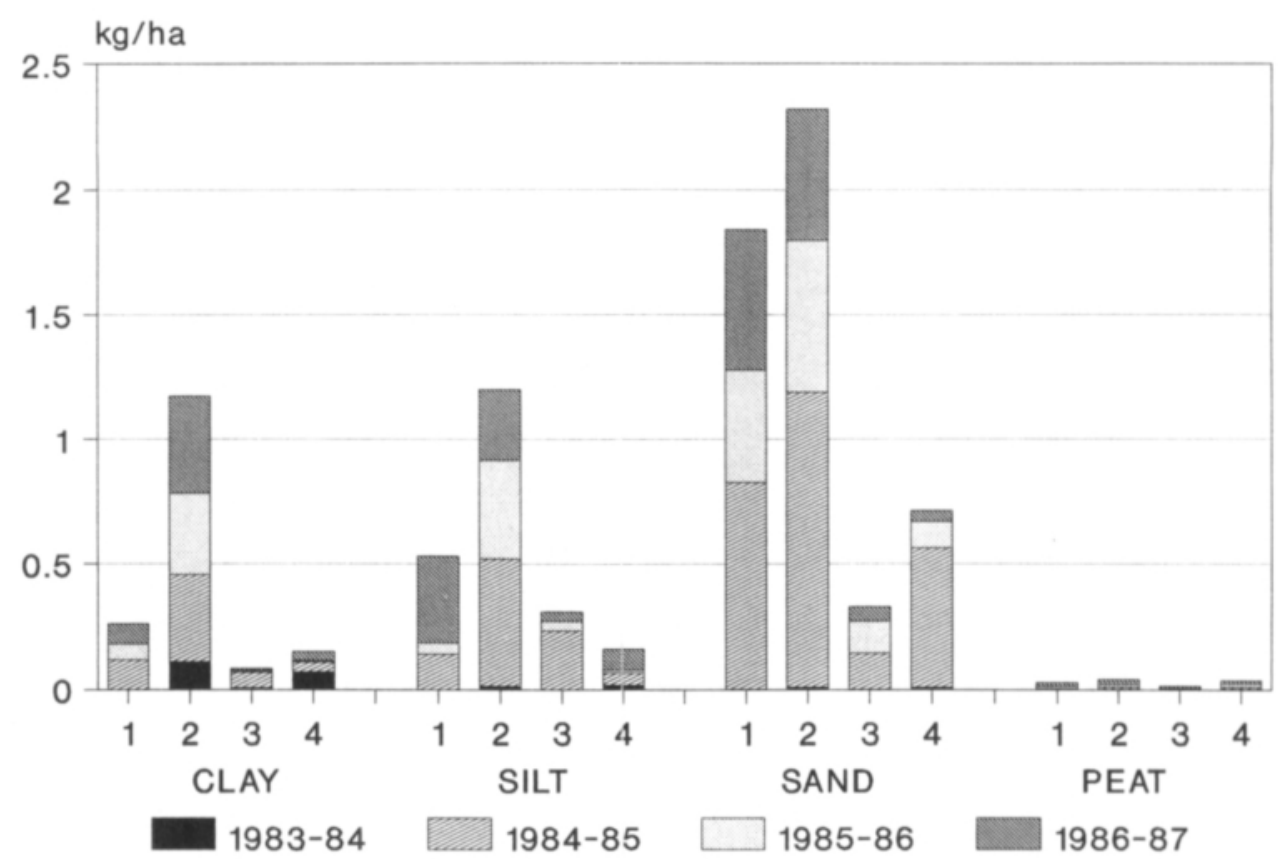

Fig. 5. Leaching of ${ }^{15} \mathrm{~N}$-labelled nitrogen added in $1983\left(100 \mathrm{~kg} \mathrm{ha}^{-1}\right.$ of $\mathrm{N}$ to mineral soils and $50 \mathrm{~kg} \mathrm{ha}^{-1}$ of $\mathrm{N}$ to peat soil) in barley lysimeters in 1983-1987. Treatments: $1=$ unirrigated barley; 2 = irrigated barley; $3=$ unirrigated grass ley; 4 = irrigated grass ley.

during the whole experimental period. Only $0.0-2.3$ $\%(0.0-2.3 \mathrm{~kg})$ and $0.0-0.7 \%{ }^{15} \mathrm{~N}$-labelled nitrogen was analyzed in waters drained through the barley and grass lysimeters, respectively (Fig. 5). The losses from the barley lysimeters during the last year were relatively great in mineral soils. Thus, some more fertilizer nitrogen would probably be leached during the next few years.

The soil analysis made at the end of the experiment helped to some extent to understand the fate of ${ }^{15} \mathrm{~N}$-labelled nitrogen. In mineral soils, $9-22 \%$ $(\mathrm{kg})$ of the originally added nitrogen was recovered (Table 4). The respective figure was in peat soil $3-47 \%$ or $2-24 \mathrm{~kg}$. Most of the fertilizer nitrogen retained by the soil at the end of the experiment was recovered in the top layer $(0-20 \mathrm{~cm}), 68-82 \%$ and $44-64 \%$ in mineral and peat soils, respectively.

Even tens of percents of ${ }^{15} \mathrm{~N}$-labelled nitrogen was missing. Part of it was probably fixed in the roots of plants which were not analyzed in detail. On the other hand, part of fertilized nitrogen fixed in the roots has inevitably been included in the soil analysis. The analytical errors considered, the fate of unrecovered labelled nitrogen added to the lysimeters at the beginning of the experiment still remains unclear. Most of it is possibly denitrified and thereby volatilized into the air. Because the denitrification was not measured, no figures could be given.

\section{Discussion}

The main part of ${ }^{15} \mathrm{~N}$-labelled nitrogen was taken up during the first experimental season, and 59$40 \%$ of the added nitrogen was not recovered in the yields. Barley took up $91-96 \%$ during the first year. The figures were about the same in the barley and grass-after-barley lysimeters. These results agree very well with the results reported by WEBSTER et al. (1986). In the first growing season, in their experiment, shoots of winter wheat at harvest contained 46 and $58 \%$ of the fertilizer nitrogen applied to the clay and sandy loam soils, respectively. In the 
following year the crops contained $1-2 \%$ of the labelled fertilizer.

The leaching and surface run-off of nitrogen is almost equal in Sweden and Finland, 18 and $15 \mathrm{~kg}$ $\mathrm{ha}^{-1}$, respectively (Nordiske seminar- og arbejdsrapporter 1992). These leaching values are similar to those measured in the cropped mineral soils in this experiment. However, the nitrogen leaching in peat soils was in our experiment much smaller. The use and also the leaching of nitrogen are clearly greater in Denmark than in the other Nordic countries. For instance, SIMMELSGAARD (1985) has reported for the coarse sandy soil the average yearly estimate for nitrogen leaching to be 44 and $47 \mathrm{~kg}$ of $\mathrm{N}$ per hectare for irrigated and unirrigated grass, respectively.

Slightly less water was drained from the undisturbed soil profiles in the monolith lysimeters than from the lysimeters filled with loose soil and compacted artificially. However, more nitrogen was leached from the silt and peat monoliths than from the corresponding filled lysimeters. In sand the difference was opposite. This agrees with the results reported by BERGSTRÖM (1987). In silt and peat soil the nitrogen leaching was clearly higher in the monolith lysimeters than in the filled lysimeters but in sand soil twice that in monoliths. Especially the functioning of filled peat lysimeters was obscure. Therefore, the use of monolith lysimeters with undisturbed soil structure would most likely be the best way in leaching experimentation with lysimeters. According to GoulDING et al. (1990), lysimeters, ceramic probes and soil sampling do not seem to give similar estimates of nitrate leaching.

The nitrogen mobilized from fallow is at risk to leaching (e.g. LONG and HUCK 1980), as it was in our experiment, because there is no crop uptake of water and nitrogen mineralized from soil organic matter over summer and autumn period. The high water drainage enhanced the nitrogen leaching.

The mechanism of nitrogen leaching seems to be complicated, because only a minor part of leached nitrogen comes from the fertilizer. MACDONALD et al. (1989) reported that for soil growing winter wheat almost all of the nitrate at risk to leach over the winter period comes from mineralization of organic $\mathrm{N}$, not from unused fertilizer applied in spring. This agrees very well with our findings, as only $0-2.3 \%\left(0-2.3 \mathrm{~kg} \mathrm{ha}^{-1}\right)$ of labelled nitrogen was recovered in water drained through the lysimeters, whereas tens of percents of labelled nitrogen was recovered in soil at the end of the experiment.

The small leaching of fertilizer nitrogen after the application has been published in many other papers, e.g. DOWDELl et al. (1984), WEBSTER et al. (1986) and DRESSEL and JUNG (1990). Little of the nitrogen applied in the spring to a cereal crop is leached before passing through the immobilizationmineralization cycle, and the nature of this process ensures that a single application makes only a small immediate contribution to the nitrate in drainage water. In the experiment conducted by WEBSTER et al. (1986), leaching losses over 5 and 6 years from the clay and sandy loam soil were respectively 1.3 and $3.9 \%$ of the original application.

The small leaching losses of nitrogen in the years followed by nitrogen application seem to be true also for high rates of nitrogen application. Over 3 years of the experiment in grassed monolith lysimeters, $0.14 \%, 3.1 \%$ and $18.1 \%$ of the applied ammonium nitrate fertilizer was recovered in the leachate at 250,500 and $900 \mathrm{~kg} \mathrm{ha}^{-1} \mathrm{a}^{-1}$ of $\mathrm{N}$, respectively (BARRACLOUGH et al. 1984).

GouldING et al. (1990) have given a very interesting picture of the influence of long-term application of nitrogen on the concentration of nitrate in leaching waters. They report that concentrations of $\mathrm{NO}_{3}^{-}-\mathrm{N}$ in drainage water are very much dependent on soil type and cropping, and they have changed little in the last 10 to 20 years despite increasing applications of fertilizer $\mathrm{N}$.

MACDONALD et al. (1989) reported that on average $17 \%$ of the $\mathrm{N}$ from spring-applied ${ }^{15} \mathrm{~N}$-labelled fertilizer remained in the $0-23 \mathrm{~cm}$ soil layer at harvest but only a small proportion was in inorganic form (ammonium+nitrate). This confirms our conclusion very well, too. Obviously, most of the nitrogen remaining in the soil is converted into organic form by soil micro-organisms and therefore fixed in soil.

The loss of nitrogen caused by denitrification is very difficult to determine exactly. Therefore, we did not have any opportunity to analyze the possible loss of fertilized nitrogen in the denitrification 
processes. According to the laboratory study conducted by YLÄrANTA and JAAKKOLA (1985), the possible loss of fertilized nitrogen can be as much as $10-20 \%$. This is about the same as the value calculated from the output values given for Sweden and Finland (Nordiske seminar- og arbejdsrapporter 1992).

In the experiment conducted by COLBOURN (1985), denitrification losses from a clay soil in Southern England from direct-drilled land averaged $5-10 \mathrm{~kg} \mathrm{ha}^{-1} \mathrm{a}^{-1}$ of $\mathrm{N}$ with great seasonal variation. Smaller gaseous losses of nitrogen from soils cropped with wheat, $1-3 \mathrm{~kg} \mathrm{ha}^{-1} \mathrm{a}^{-1}$ of $\mathrm{N}$, have been published by AULAKH et al. (1983). Losses of nitrogen from summer fallow fields were 2-5 times higher than when the same fields were cropped. The rate of gaseous $\mathrm{N}$ losses increased from 6 to 10 times following rainfall events.

The nitrogen balance calculations in our lysimeter experiment are not very accurate, because of errors accumulating from plant, water and soil analysis. Therefore, the figures which could be calculated from nitrogen balance values for nitrogen volatilization and denitrification are uncertain but do not disagree with the studies referred to above.

\section{References}

Aulakh, M.S., Rennie, D.A. \& Paul, E.A. 1983. Field studies on gaseous nitrogen losses from soils under continuous wheat versus a wheat-fallow rotation. Plant and Soil 75: $15-27$.

Barraclough, D., Geens, E.L. \& Maggs, J.M. 1984. Fate of fertilizer nitrogen applied to grassland. II. Nitrogen-15 leaching results. J. Soil Sci. 35: 191-199.

Bergström, L. 1987. Nitrate leaching and drainage from annual and perennial crops in tile-drained plots and lysimeters. J. Environ. Qual. 16: 11-18.

Colbourn, P. 1985. Nitrogen losses from the field: denitrification and leahcing in intensive winter cereal production in relation to tillage method of a clay soil. Soil Use and Management. 1: 117-120.

Dowdell, R.J., Webster, C.P., Hill, D. \& Mercer, E.R. 1984. A lysimeter study of the fate of fertilizer nitrogen in spring barley crops grown on shallow soil overlying Chalk: crop uptake and leaching losses. J. Soil Sci. 35: 169-181.

Dressel, J. \& JUNG, J. $1990 .{ }^{15} \mathrm{~N}$ studies of the behavior of fertilizer nitrogen in three different soils (lysimeter trials). J. Agronomy \& Crop Sci. 164: 217-223.

EEC 1980. Council directive on the quality of water for human consumption. Official J. No 80/778 European Economic Community L229, 11.

Goulding, K.W.T., Johnston, A.E., Webster, C.P. \& Howe, M.T. 1990. Losses of nitrate from arable land by leaching and their effect on nitrates in drainage and groundwater. p. 26-34. In: Merckx, R. et al. (eds.). Fertilization and the environment. Leuven University Press.

JAAKKOLA, A. 1984. Leaching losses of nitrogen from a clay soil under grass and cereal crops in Finland. Plant and Soil 76: 59-66.
— 1985. Maan lämpötilan ja kosteuden vaikutus ammoniumnitraattilannoituksen tehoon. Abstract: Influence of soil temperature and moisture on the fertilizer effect of ammonium nitrate. In: Lannoite- ja kasviainestypen hyväksikäyttö ja typen häviö. SITRA:n julkaisu 13. p. 1-50.

— \& Yläranta, T. 1985. Typen huuhtoutuminen ja hyväksikäyttö lysimetrikokeessa. Abstract: Leaching of nitrogen and its utilization by plant in lysimeters. In: Typen hyväksikäyttö ja häviö lysimetri- ja astiakokeissa. SITRA:n julkaisu 22. p. 1-38.

KJellerup, V. \& KofOEd, A. DAM. 1983. Kvæstofgodskningens indflydelse på udvaskning af plantenæringsstoffer fra jorden. Lysimeterforsog med anvendelse af ${ }^{15} \mathrm{~N}$. Tidsskr. Planteavl. 87: 1-22.

Leinonen, L. \& Juntro, S. (eds.). 1992. Ilmanlaatumittauksia - Air quality measurements 1991. Ilmatieteen laitos. Finnish Meteorological Institute. 220 p. Helsinki.

LoNG, F.L. \& Huck, M.G. 1980. Nitrate movement under corn and fallow conditions. Soil Sci. Soc. Am. J. 44: 787-792.

Macdonald, A.J., Powlson, D.S., Poulton, P.R. \& Jenkin. son, D.S. 1989. Unused fertilizer nitrogen in arable soils - its contribution to nitrate leaching. J. Sci. Food Agric. 46: 407-419.

—, Poulton, P.R. \& Powlson, D.S. 1990. Sources of nitrate leaching from arable soil to aquifers. In: Merckx, R. et al. (eds.). Fertilization and the environment. Leuven University Press. p. 281-288.

Nordiske seminar- og arbejdsrapporter 1992: 594. Leaching and runoff of nitrogen from agricultural areas in the Nordic Countries. $68 \mathrm{p}$ and appendix 1.

SCharF, P.C. \& Alley, M.M. 1989. Understand nitrogen loss pathways. Solutions. Feb. 1989: 34-44. 
SimmelsgaArd, Sv.E. 1985. Vandbalance og kvælstofudvaskning på 4 jordtyper. III. Kvælstofkoncentration, -udvaskning og -balance. Tidsskr. Planteavl 89: 133-154.

Webster, C.P., Belford, R.K. \& CANNell, R.Q. 1986. Crop uptake and leaching losses of ${ }^{15} \mathrm{~N}$ labelled fertilizer nitrogen in relation to waterlogging of clay and sandy loam soils. Plant and Soil 92: 89-101.

YLÄrantA, T. \& JAAKKOLA, A. 1985. Lannoitetypen häviö märässä ja tiiviissä maassa. Abstract: Loss of fertilizer nitrogen in wet and compact soil. In: Typen hyväksikäyttö ja häviö lysimetri- ja astiakokeissa. SITRA:n julkaisu 22. p. 39-53.

\section{Manuscript received March 1993}

Toivo Yläranta

Jaana Uusi-Kämppä

Agricultural Research Centre of Finland

Institute of Soils and Environment

FIN-31600 Jokioinen, Finland

Antti Jaakkola

Department of Applied Chemistry and Microbiology

P.O.Box 27

FIN-00014 University of Helsinki, Finland

\title{
SELOSTUS
}

\section{Typen huuhtoutuminen eri maalajeissa}

\author{
TOIVO YläRANTA, JAANA UUSI-KÄMPPÄ ja ANTTI JAAKKOLA
}

Maatalouden tutkimuskeskus ja Helsingin yliopisto

Nelivuotisessa lysimetrikokeessa tutkittiin typen huuhtoutumista savi- ja hiesumaasta, karkeasta hietamaasta ja saraturvemaasta. Koekasveina olivat Kustaa-ohra ja timotei-nurminataseos. Puolet viljellyistä lysimetreistä lannoitettiin normaalin viljelykäytännön mukaisesti toisen puolen jäädessä lannoittamatta. Osa lysimetreistä pidettiin kesantona. Yhtenä koetekijänä oli myös sadetus. Lannoitetypen huuhtoutumisen ja kasvien lannoitetypen oton selvittämiseksi lisättiin osaan lysimetreistä ensimmäisenä koevuonna ${ }^{15} \mathrm{~N}$-merkittyä ammoniumnitraattia.

Kivennäismaiden ohran vuotuinen typpilannoitus oli koko kokeen ajan $100 \mathrm{~kg} / \mathrm{ha}$. Saraturpeen ohran typpilannoitus oli puolet kivennäismaiden ohran typpilannoituksesta. Timoteinurminata -nurmea, koevuodet 1984-1986, lannoitettiin kuten ohraa, mutta lannoitus annettiin molemmille sadoille samansuuruisena eli vuotuiseksi typpimääräksi tuli N $200 \mathrm{~kg} / \mathrm{ha}$ kivennäismailla ja puolet tästä saraturvemaalla.

Savi- ja hietamaan kesannosta huuhtoutui typpeä vuosittain yli $100 \mathrm{~kg} / \mathrm{ha}$. Hiesu- ja turvemaassa typen huuhtoutuminen kesannosta oli joinakin vuosina vain muutamia kiloja hehtaarilta. Voimakas kastelu lisäsi joinakin vuosina typen huuhtoutumisen kesannosta moninkertaiseksi kastelemattomaan verrattuna. Toisinaan kastelun vaikutus oli vähäinen.

Sekä lannoittamattomat että lannoitetut viljelykasvit vähensivät tehokkaasti typen huuhtoutumista, nurmi enemmän kuin ohra. Sen sijaan erot typen huuhtoutumisessa lannoitettujen ja lannoittamattomien ohra- ja nurmilysimetrien lävitse olivat usein vähäisiä.

Kastelemattomien savi-, hiesu- ja turvemaan ohra- ja nur- milysimetrien lävitse huuhtoutui typpeä vuosittain $0,5 \mathrm{~kg}: \mathrm{sta} /$ ha $10,5 \mathrm{~kg}: \mathrm{aan} / \mathrm{ha}$. Hietamaassa vastaavat luvut vaihtelivat 3,5 kg:sta/ha 45,6 kg:aan/ha. Kastelu lisäsi voimakkaasti huuhtoutuvia typpimääriä erityisesti kivennäismaissa, mutta myös useissa turvemaan koejäsenissä.

Sadetus oli tässä kokeessa niin runsas, noin $300 \mathrm{~mm}$ kasvukauden aikana, ettei se käytännössä juuri tule kysymykseen. Tulos osoitti, että kasvukauden poikkeuksellinen sateisuus voi lisätä typen huuhtoutumista.

Kokeen alussa, vuonna 1983, annetusta ${ }^{15} \mathrm{~N}$-merkitystä lannoitetypestä huuhtoutui kokeen aikana vuosina 1983-1987 erittäin vähän. Eniten lannoitetyppeä huuhtoutui kastellusta hiedasta. Kun siinä viljeltiin neljänä peräkkäisenä vuotena ohraa, joutui ensimmäisen vuoden lannoitetypestä koko kokeen aikana $2,3 \%$ eli $2,3 \mathrm{~kg} /$ ha valumaveteen. Turpeen lävitse huuhtoutuneista valumavesistä ei vuoden 1983 lannoitetyppeä löydetty juuri lainkaan.

Lysimetrikoe osoitti selvästi, että kohtuullisen typpilannoituksen vaikutus typen huuhtoutumiseen viljelymaista on vähäinen. Sen sijaan kesantopellosta, jossa ei viljellä lainkaan kasveja, typen huuhtoutuminen saattaa olla runsasta.

Lannoitetypestä vain noin puolet kertyi lannoitusvuonna ohran maanpäällisiin osiin lopun jäädessä pääosin maahan tai haihtuessa ilmaan. Lannoitetypen biologinen pidättyminen maahan ja sen siellä läpikäymä ilmeisen monimutkainen prosessi kaipaa tutkimustyötä. Epäselväksi jäi muun muassa se, kuinka monta vuotta lannoitetypen huuhtoutuminen kestää. Selvittämistä odottaa myös denitrifikaation vaikutus lannoitetypen kohtaloon suomalaisessa viljelymaassa. 